\title{
Scots Pine Seedlings Growth Under Different Ca/Mn Soil Ratios
}

\author{
Liudmyla Romanchuk ${ }^{1}$, Pavlo Didenko ${ }^{1,}$, , Nazariy Sus ${ }^{2}$, Volodymyr Ustymenko ${ }^{1}$, \\ Anatolii Orlovskyi ${ }^{3}$ \\ ${ }^{1}$ Department of Biology and Forest Protection, Faculty of Forestry, Polissia National University, Zhytomyr, Ukraine \\ ${ }^{2}$ Laboratory of Ecology of Viruses and Biosafety, Department of Agroecology and Biosafety, Institute of Agroecology and Environmental \\ Management of National Academy of Agrarian Sciences of Ukraine, National Academy of Agrarian Sciences of Ukraine, Kyiv, Ukraine \\ ${ }^{3}$ Department of Virology, Health and Propagation of Fruit and Berry Crops, Institute of Horticulture of National Academy of Agrarian \\ Sciences of Ukraine, National Academy of Agrarian Sciences of Ukraine, Novosilky, Ukraine
}

\section{Email address: \\ Wood112@ukr.net (P. Didenko) \\ ${ }^{*}$ Corresponding author}

\section{To cite this article:}

Liudmyla Romanchuk, Pavlo Didenko, Nazariy Sus, Volodymyr Ustymenko, Anatolii Orlovskyi. Scots Pine Seedlings Growth Under Different Ca/Mn Soil Ratios. International Journal of Ecotoxicology and Ecobiology. Vol. 6, No. 2, 2021, pp. 34-40.

doi: $10.11648 /$ j.ijee.20210602.12

Received: June 18, 2021; Accepted: June 28, 2021; Published: July 8, 2021

\begin{abstract}
Low $\mathrm{Ca} / \mathrm{Mn}$ ratios in soils are considered one of the causes of forest decline in the northern hemisphere, in particular, Scots pine forest decline. Nevertheless, there are little data on the growth and development of forest trees, especially Scots pine, under different soil concentrations of calcium and manganese. Therefore, the present study aims to estimate Scots pine seedlings' height growth under different $\mathrm{Ca} / \mathrm{Mn}$ soil ratios. For this purpose, we measured the height of 8-month-old Scots pine seedlings that grew on two adjacent plots, whose soils had different origins and, therefore, differed significantly in their properties. Some of these soil properties, namely exchangeable and hydrolytic acidity, the sum of absorbed bases, the content of humus, alkali-hydrolyzable nitrogen, exchangeable potassium and calcium, mobile sulfur and phosphorus, mobile compounds of copper, zinc, cobalt, cadmium, lead, and manganese, were determined by various methods. Pairwise comparison of values of listed above properties of soils from these experimental plots revealed that these soils differed significantly in manganese and calcium content and acid-basic properties. Therefore, as the ratio of molal concentrations of exchangeable calcium to manganese mobile compounds $(\mathrm{Ca} / \mathrm{Mn}$ ratio) in the soil is a parameter that combines those soil properties that differed significantly between the two plots, we used the one-way ANOVA to verify the association between Ca/Mn ratio and Scots pine seedlings' height growth rate. As a result, this analysis revealed a statistically significant difference $(\mathrm{p}<0.05)$ in mean height between Scots pine seedlings that grew under relatively low (45.28/1) and relatively high Ca/Mn ratio (195.12/1) in soil. Nevertheless, although the mean height of Scots pine seedlings that grew at the ratio of 45.28/1 was approximately 1.6 times lower than seedlings that grew at the ratio of 195.12/1, the optimum value of the Ca/Mn ratio in the soil for Scots pine remains unknown. In addition, the hypothesis that untested soil properties have also caused the differences in the mean height of seedlings was not rejected. Thus, the impact of the $\mathrm{Ca} / \mathrm{Mn}$ ratio together with the potential impact of untested soil properties on the growth and development of Scots pine and the optimum value of this ratio for this species needs to be investigated in further studies.
\end{abstract}

Keywords: Scots Pine, Pinus Sylvestris, Ca/Mn Ratio, Exchangeable Calcium, Mobile Manganese

\section{Introduction}

Scots pine (Pinus sylvestris L.) is the most widespread conifer species in the world, covering nearly $3.7 \%$ of the total world forest area [1]. P. sylvestris is also one of the most important sources of wood raw material in Eurasia [2]. This species is widespread from Siberia to Iberia and grows under a large range of climatic and edaphic conditions. For 
example, Scots pine can grow with annual precipitation between 200 and 2,000 $\mathrm{mm}$ [3]. However, despite the broad ecological tolerance of this species, Scots pine forests, like the other coniferous forests, are declining across the world [4]. In Ukraine, Scots pine forests, which represent 33\% of the forests, are declining on a large scale and the foci of Scots pine forest mortality now cover over $10 \%$ of the forested area in some regions [5]. Although, in general, the forest decline is a consequence of the anthropogenic impact, a wide range of causes of forest mortality have been reported in the literature. Soil calcium depletion is one of these causes.

Calcium depletion played a key role in the declining North American temperate forests, including forests of Picea rubens Sarg., and forests of southern China, such as forests of Pinus massoniana Lamb. [6, 7]. In addition, recent studies of the drought-induced forest dieback in northeastern Spain have shown that $P$. sylvestris and Abies alba Mill forest mortality was caused by long-term nutrient imbalances [8]. Specifically, this study showed that differences between declining and non-declining trees of both species were the highest in tree-ring $\mathrm{Ca} / \mathrm{Mn}, \mathrm{Mn} / \mathrm{Al}$, and $\mathrm{P} / \mathrm{Mn}$ ratios [8]. Furthermore, the latest study from China indicated that exogenous $\mathrm{Ca}^{2+}$ supplementation and ectomycorrhizal fungi (Suillus luteus (L.) Roussel (1796)) inoculation together can enhance the drought tolerance of Pinus sylvestris var. mongolica seedlings $[9,10]$. Thus, calcium deficiency is one of the causes of Scots pine forest decline.

Calcium deficiency can be caused by various anthropic disturbances. The main ones are forest harvesting and acidic deposition [11-13]. Acidic deposition, or acid rain, is depleting the soil calcium $(\mathrm{Ca})$ from pools and can limit the uptake and incorporation of $\mathrm{Ca}$ in trees. Acid deposition can also leach calcium from needles [11-13]. Forest harvesting removes calcium and other base cations that accumulated in the tree from forest ecosystems. The loss of base cations $\left(\mathrm{Ca}^{2+}, \mathrm{Mg}^{2+}, \mathrm{Na}^{+}, \mathrm{K}^{+}\right)$due to forest harvesting leads to soil acidification [14]. Acidic deposition also causes soil acidification [15]. Soil acidification, in turn, leads to increased solubilization and availability of potentially phytotoxic non-base cations $\left(\mathrm{Mn}^{2+}\right.$ and $\left.\mathrm{Al}^{3+}\right)$. These potentially phytotoxic non-base cations interfere with the uptake, transport, and utilization of $\mathrm{Ca}$ and other base cations, which results in, among others, calcium deficiency $[16,17]$. However, the solubility and therefore availability and potential phytotoxicity of $\mathrm{Mn}^{2+}$ and $\mathrm{Al}^{3+}$ depend on the redox potential and $\mathrm{pH}$ of the soil and these non-base cations dominate in the soil solution at different ranges of $\mathrm{pH}$ [18]. For example, Mn phytotoxicity generally occurs at soil $\mathrm{pH}$ values between 4.0 and 5.5, whereas Al phytotoxicity usually occurs at soil $\mathrm{pH}$ values below $4[19,20]$. Thus, aluminum and manganese induce calcium deficiency in various forest tree species at distinct phases of soil acidification.

Although the Al- and Mn-induced Ca deficiency is one of the causes of forest decline in the northern hemisphere, there are little data on the growth and development of forest trees, especially Scots pine, under different soil concentrations of calcium, manganese, and aluminum. At the same time, given the antagonism between non-base cations and calcium, the elemental ratios such as $\mathrm{Ca} / \mathrm{Mn}$ and $\mathrm{Ca} / \mathrm{Al}$ are better indicators of calcium deficiency caused by soil acidification and/or nutrient imbalances compared to single elemental concentrations (e.g., Ca, Al, Mn). The purpose of the study, therefore, was to estimate Scots pine seedlings' height growth under different $\mathrm{Ca} / \mathrm{Mn}$ soil ratios.

\section{Methods}

\subsection{The Timing and Location of Field Research}

The study was carried out at the forest nursery of Korbutivka forestry. This forestry belongs to the state-owned enterprise «Zarichanske lisove hospodarstvo» and is located in Zhytomyr Oblast, Ukraine. This study consisted of several stages. On 28 April 2020, Scots pine seeds were planted at two distinct plots. These plots differed in soil, namely the soil of these plots originated from distinct sources. On 10 June 2020, soil samples were obtained from these plots for further agrochemical laboratory tests. On 28 December 2020, the height of 10 8-month-old Scots pine seedlings was measured at each plot.

\subsection{Agrochemical Laboratory Tests}

Agrochemical laboratory tests have been conducted by the Measuring Laboratory of Polissia National University following the relevant State Standards of Ukraine (DSTU) or State Standards of Soviet Union (GOST). In particular, values of the indicators, which are shown in tables 1-3 below were obtained in conformity with the following standards:

a. DSTU ISO 10390-2007 [21] for exchangeable acidity;

b. DSTU 7537: 2014 [22] for hydrolytic acidity;

c. GOST 27821-88 [23] for the sum of absorbed bases;

d. DSTU 4289: 2004 [24] for humus content;

e. DSTU 7863: 2015 [25] for soil alkali-hydrolysable nitrogen $(\mathrm{N})$ content;

f. DSTU 4405: 2005 [26] for mobile phosphorus (P) content and exchangeable potassium $(\mathrm{K})$ content;

g. GOST 26487-85 [27] for exchangeable calcium (Ca) content;

h. DSTU 8347: 2015 [28] for mobile sulfur (S) content;

i. DSTU 4770.6: 2007 [29] for content of mobile compounds of copper $(\mathrm{Cu})$;

j. DSTU 4770.2: 2007 [30] for content of mobile compounds of zinc $(\mathrm{Zn})$;

k. DSTU 4770.5: 2007 [31] for content of mobile compounds of cobalt $(\mathrm{Co})$;

1. DSTU 4770.3: 2007 [32] for content of mobile compounds of cadmium $(\mathrm{Cd})$

m.DSTU 4770.9: 2007 [33] for content of mobile compounds of lead $(\mathrm{Pb})$;

n. DSTU 4770.1: 2007 [34] for content of mobile compounds of manganese $(\mathrm{Mn})$.

Note that flame atomic absorption spectrophotometer (FAAS) C115-M1 ("SELMICHROM", Ukraine) was used to measure phosphorus, potassium, calcium, sulfur, copper, 
zinc, cobalt, cadmium, lead, and manganese content in soil samples. Also, soil samples were collected according to DSTU ISO 10381-2: 2004 [35].

The content values of heavy metal mobile forms obtained during the study had been interpreted by comparing them to permissible content values of heavy metal mobile forms in sod-podzolic soils, according to Ukrainian soil hygiene regulations [36].

\subsection{Statistical Analyses}

The values of Scots pine seedlings' height were indicated as the sample mean \pm standard error (SE). The effects of $\mathrm{Ca} / \mathrm{Mn}$ molal ratios on Scots pine seedlings height growth were analyzed via one-way analysis of variance (abbreviated one-way ANOVA) using the Analysis ToolPak (free add-in to
Microsoft Office Excel). The $\mathrm{Ca} / \mathrm{Mn}$ molal ratio was used in this analysis as a factor with two levels.

\section{Results}

\subsection{Pairwise Comparison of the Experimental Plot Conditions}

In this study, we investigated Scots pine seedlings' growth under different $\mathrm{Ca} / \mathrm{Mn}$ soil ratios. The study was conducted at two adjacent plots, differing only in soil conditions to reject non-soil conditions influences. Moreover, we also measured other agrochemical soil indicators to identify other potential differences in soil conditions of experimental plots. These soil differences are described below.

Table 1. Acid-basic properties of experimental plot soils.

\begin{tabular}{llll}
\hline Plots & Exchangeable acidity, $\mathbf{p H}$ units & Hydrolytic acidity, $\mathbf{~} g-\mathbf{e q} / \mathbf{1 0 0} \mathbf{g}$ of soil & Sum of absorbed bases, $\mathbf{m g - e q} / \mathbf{1 0 0} \mathbf{g}$ of soil \\
\hline P1 & 5.92 & 5.03 & 39.0 \\
P2 & 4.34 & 4.05 & 30.0 \\
\hline
\end{tabular}

Exchangeable acidity, hydrolytic acidity, and the sum of absorbed bases were estimated to compare acid-basic soil properties of the experimental plots. Values for these indicators are presented in Table 1. Soil samples from the plot 2 (P2) had significantly lower values of these indicators compared to values of samples from the plot 1 (P1). In general, the soil at the P1 was slightly acidic, while the soil at the P2 was strongly acidic.

Since soil fertility directly depends on the quantity of humus in the soil we measured the humus content (\%) in the soil of experimental plots. Humus mass fraction in soil at P1 and $\mathrm{P} 2$ was equal, as shown in Table 2 below.

Table 2. Macronutrient status and humus content of experimental plot soils.

\begin{tabular}{|c|c|c|c|c|c|c|}
\hline Plots & Humus content & Soil alkali-hydrolysable $N$ content & Mobile $P$ content & Exchangeable $K$ content & Ca content & S content \\
\hline Units & $\%$ & $\mathrm{mg} / \mathrm{kg}$ soil & & & \multicolumn{2}{|c|}{ mmol/ 100 g soil } \\
\hline P1 & 2.01 & 39.2 & 37.89 & 41.4 & 7.75 & 3.96 \\
\hline $\mathrm{P} 2$ & 2.01 & 28.0 & 26.71 & 33.4 & 2.87 & 2.96 \\
\hline
\end{tabular}

In general, plant nutrients are divided into macronutrients and micronutrients. Macronutrients include nitrogen, phosphorus, potassium, sulfur, magnesium, and calcium. The content of some macronutrients, namely alkali-hydrolyzable nitrogen $(\mathrm{N})$, mobile phosphorus (P), exchangeable potassium $(\mathrm{K})$, exchangeable calcium $(\mathrm{Ca})$, and mobile sulfur (S) content in soil samples from P1 and P2 are shown in Table 2 above. The content of these macronutrients in soil samples from P1 was higher than in soil samples from P2. In particular, the alkali-hydrolyzable nitrogen, mobile phosphorus, exchangeable potassium, and mobile sulfur content in soil samples from P1 was approximately 1.4, 1.42, 1.24 , and 1.34 times higher, than in soil samples from $\mathrm{P} 2$, respectively. However, the ratio between the exchangeable calcium content in the soil sample from P1 and the exchangeable calcium content in the soil sample from P2 was highest compared to respective ratios for other studied macronutrients. More specifically, the exchangeable calcium content in soil samples from P1 was approximately 2.7 times higher, than in soil samples from $\mathrm{P} 2$. Thus, soil samples from $\mathrm{P} 1$ and P2 did not differ significantly in the macronutrient status, except for exchangeable calcium content.

Some metals can inhibit the growth and reduce biomass production of the plant. Such metals are called heavy metals and / or toxic metals. They include arsenic (As), cadmium $(\mathrm{Cd})$, chromium $(\mathrm{Cr})$, cobalt $(\mathrm{Co})$, lead $(\mathrm{Pb})$, mercury $(\mathrm{Hg})$, nickel $(\mathrm{Ni})$, vanadium $(\mathrm{V})$, copper $(\mathrm{Cu})$, iron $(\mathrm{Fe})$, manganese $(\mathrm{Mn})$, and zinc $(\mathrm{Zn})$ and some other metals. Importantly, heavy metals like copper, iron, manganese, and zinc are also micronutrients. No less importantly, the bioavailability of heavy metals in soils depends on their mobility. Given the above, we measured the content of some heavy metal mobile compounds, namely content of copper, zinc, cobalt, cadmium, lead, and manganese mobile forms in soil samples from P1 and P2. Concentrations of these heavy metal mobile forms in soil samples from P1 and P2 are presented in Table 3 . The content of these heavy metal mobile compounds in soil samples from P1 was higher than in soil samples from $\mathrm{P} 2$, except for contents of cadmium and manganese mobile forms. In particular, concentrations of copper and zinc mobile forms in soil samples from P1 were marginally higher than in soil samples from P2, whereas concentrations of cobalt and lead mobile forms in soil samples from P1 were approximately 2 and 2.17 times higher than in soil samples from P2, respectively. However, despite these differences in the content of cobalt and lead mobile compounds in soil samples from P1 and P2, their mobile compounds contents were relatively low in all soil samples. More specifically, 
concentrations of cobalt and lead mobile forms in all soil samples were many times lower than their maximum permissible concentrations (hereafter abbreviated as MPCs), which are listed in Table 3 below. As for the content of cadmium mobile compounds, concentrations of cadmium mobile compounds in all soil samples were equal. Contrary to the contents of macronutrients and mobile compounds of other heavy metals, the content of manganese mobile compounds was higher in soil samples from P2 than in soil samples from P1. More specifically, the mass concentration of manganese mobile compounds in soil samples from P2 was approximately 1.6 times higher than in soil samples from P1. Furthermore, while concentrations of mobile forms of all heavy metals in all soil samples were lower than their MPCs, the lowest ratio between the concentration in sample and MPC was found for manganese mobile forms. Thus, plot 1 and plot 2 differed most in calcium and manganese contents and acid-basic properties. Based on these differences, we researched Scots pine seedlings' growth under different $\mathrm{Ca} / \mathrm{Mn}$ soil ratios.

Table 3. The content of heavy metal mobile compounds in experimental plot soils.

\begin{tabular}{lllllll}
\hline \multirow{2}{*}{ Plots } & \multicolumn{2}{l}{ The content of mobile compounds of heavy metals, mg/kg soil } \\
\cline { 2 - 7 } & Copper $(\mathbf{C u})$ & Zinc (Zn) & Cobalt (Co) & Cadmium (Cd) & Lead (Pb) & Manganese (Mn) \\
\hline P1 & 0.28 & 1.86 & 0.0002 & 0.05 & 0.76 & 21.82 \\
P2 & 0.24 & 1.42 & 0.0001 & 0.05 & 0.35 & 34.82 \\
MPCs* & 3.0 & 23.0 & 5.0 & - & 6.0 & $60.0($ at pH 4.0) or 80.0 (at pH 5.1-6.0) \\
\hline
\end{tabular}

* The maximum permissible concentrations of heavy metal mobile forms in sod-podzolic soils under Ukrainian legislation [36].

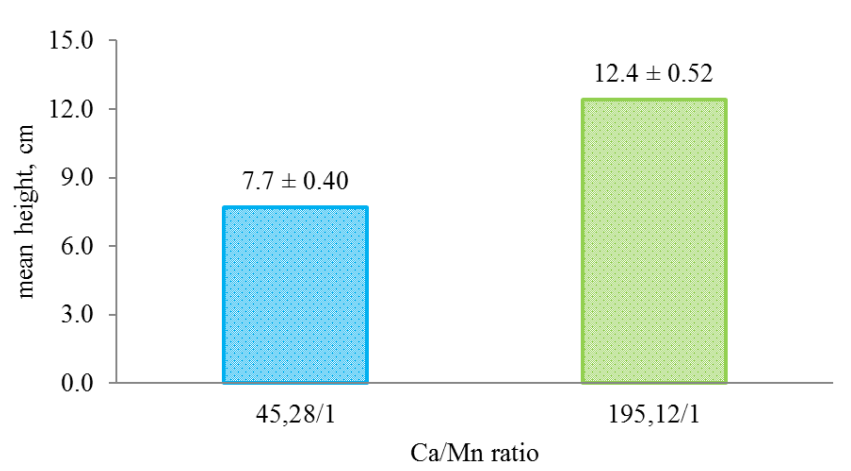

Figure 1. Scots pine seedlings height growth under different $\mathrm{Ca} / \mathrm{Mn}$ soil ratios $(p<0.05)$.

\subsection{The Height Growth of Scots Pine Seedlings Under Different Ca/Mn Soil Ratios}

Given the above differences between the soil samples, we measured the height of the 8-month-old Scots pine seedlings that grew on experimental plots to test the potential influence of these differences on their height growth. As a result, the mean height of seedlings that were grown on the experimental plot $1(\mathrm{P} 1)$ was 1,61 times bigger than seedlings that were grown on the experimental plot 2 (P2). Since experimental plots mostly differed in calcium and manganese contents and acid-basic properties, we calculated $\mathrm{Ca} / \mathrm{Mn}$ molal ratios as the most representative indicators of these experimental plot soils, because manganese is antagonists to calcium and their bioavailability depends on acid-basic soil properties. Therefore, we tested the influence of different $\mathrm{Ca} / \mathrm{Mn}$ molal ratio values in soil on Scots pine seedlings height growth by one-way ANOVA using $\mathrm{Ca} / \mathrm{Mn}$ molal ratios as a factor with two levels. These levels expressed as $\mathrm{Ca} / \mathrm{Mn}$ molal ratios for the soil at $\mathrm{P} 1$ and $\mathrm{P} 2$ experimental plots were $45.28 / 1$ and 195.12/1, respectively. The results of this analysis are presented in [1. Thus, the one-way ANOVA showed that the influence of the $\mathrm{Ca} / \mathrm{Mn}$ molal ratio on Scots pine seedlings' height growth was statistically significant. In particular, $\mathrm{p}$-value for the influence of the $\mathrm{Ca} / \mathrm{Mn}$ molal ratio was $1.09 \times 10^{-6}$. To reject or accept the null hypothesis about the absent impact of the $\mathrm{Ca} / \mathrm{Mn}$ molal ratio, we compared the relevant obtained statistical $\mathrm{F}$-value $\left(\mathrm{F}_{\text {obt }}\right)$ against the critical $\mathrm{F}$-value $\left(\mathrm{F}_{\text {crit }}\right)$. As a result, the obtained statistical $\mathrm{F}$-value for the impact of the $\mathrm{Ca} / \mathrm{Mn}$ molal ratio was 51.64 and exceeded the critical F-value, which was 4.41. Thus, the null hypothesis was rejected.

\section{Discussion}

The design of this experiment allowed us to reject the hypothesis that the differences between the mean height of Scots pine seedlings, which grew in plot 1 (P1) and plot 2 (P2), are caused by non-soil conditions. However, according to our present findings, these plots (P1 and P2) differed significantly in the acid-basic properties of soil and cobalt, lead, calcium, and manganese contents in soil. The humus content and cadmium mobile compounds content in the soil of both plots were equal. Other parameters of soil conditions, such as contents of copper and zinc mobile compounds, alkalihydrolyzable nitrogen, mobile phosphorus, exchangeable potassium, and mobile sulfur, which were measured in this study, differed only slightly between experimental plots.

The content of cobalt mobile compounds in soil was twice as high for P1 as for P2. However, concentrations of cobalt mobile compounds in the soil at P1 and P2 were twenty-five and fifty thousand times lower than the maximum permissible concentration (MPC) of cobalt mobile compounds in sod-podzolic soils, respectively (see Table 3). In addition to this, cobalt is not an essential element for plant nutrition, and cobalt deficiency, unlike cobalt excess, does not cause adverse effects on the growth and physiology of plants in natural conditions [37]. Moreover, cobalt occurs naturally in the atmosphere, and its uptake can additionally occur through the cuticle by the leaves [37]. Therefore, in this study, we did not consider cobalt mobile compounds as a factor causing the difference in mean height between seedlings, which grew in P1 (hereafter abbreviated as SG1) and P2 (hereafter abbreviated as SG2). 
Lead is not a plant nutrient and plays no role in plant growth and development [37]. Nevertheless, the lead at relatively high concentrations in the soil is toxic and can inhibit plant growth and development [37]. For example, Yang, Zhou and Wang in 2016 [38] reported that the fifty percent inhibitory concentrations $\left(\mathrm{IC}_{50}\right)$ for seed germination rates of Pinus tabuliformis Carr. under lead nitrate $\left(\mathrm{Pb}\left(\mathrm{NO}_{3}\right)_{2}\right)$ and lead acetate $\left(\mathrm{Pb}\left(\mathrm{CH}_{3} \mathrm{COOH}\right)_{2} \cdot 3 \mathrm{H}_{2} \mathrm{O}\right)$ treatments were $3.57 \mathrm{~g} / \mathrm{kg}$ and $7.46 \mathrm{~g} / \mathrm{kg}$, respectively. These authors also showed that the $\mathrm{IC}_{50}$ for $P$. tabuliformis root lengths under lead nitrate and lead acetate treatments were $2.64 \mathrm{~g} / \mathrm{kg}$ and $6.29 \mathrm{~g} / \mathrm{kg}$, respectively, while the $\mathrm{IC}_{50}$ for stem elongations under lead nitrate and lead acetate treatments were $2.85 \mathrm{~g} / \mathrm{kg}$ and $7.81 \mathrm{~g} / \mathrm{kg}$, respectively. Thus, although the content of lead mobile compounds in the soil of P1 was approximately 2.17 times higher than in the soil of $\mathrm{P} 2$, the values of lead mobile compound concentration in soil of both plots were significantly lower, both than the MPC for lead mobile compounds in sod-podzolic soils (see Table 3 ) and $\mathrm{IC}_{50}$ of lead for forest species [38]. Therefore, the difference in mean height of seedlings between SG1 and SG2 couldn't have been caused by differences in the content of lead mobile compounds in soil.

The concentration of exchangeable calcium and mobile forms of manganese in the soil depends on the base saturation of the soil, which is directly proportional to the sum of absorbed bases, and soil acidity (exchangeable acidity, hydrolytic acidity). In particular, the increase in the value of the sum of absorbed bases and the $\mathrm{pH}$ value leads to a decrease in the mobility of non-base cations (eg, $\mathrm{Al}^{3+}$, $\left.\mathrm{Mn}^{2+}\right)$ and an increase in the exchangeability of base cations (eg, $\left.\mathrm{Ca}^{2+}, \mathrm{Mg}^{2+}\right)$. Furthermore, the exchangeable calcium and mobile compounds of manganese are plant-available forms of these elements [39]. Thus, ratios of molal concentrations of exchangeable calcium to manganese mobile compounds are a parameter that combines the above, tested soil properties and represents the main differences between experimental plots. In addition, the differences in this ratio between experimental plots were probably the main cause of differences in the mean height of seedlings between SG1 and $\mathrm{SG} 2$. However, the differences in the mean height of seedlings between SG1 and SG2 may have been partially caused by differences between experimental plots in soil properties that were not tested in this study, such as the mobile aluminum and the exchangeable magnesium content, etc. Nevertheless, according to literature data [18-20], aluminum ions become dominant in the soil solution at the soil $\mathrm{pH}<4$, while the soil $\mathrm{pH}$ of $\mathrm{P} 1$ and $\mathrm{P} 2$ were 5.92 and 4.34 , respectively. Thus, the difference in the soil aluminum contents between plots probably could not be the cause of the difference in the mean height of seedlings between SG1 and SG2. As for the other exchangeable base cations, their potential role in causing the differences in mean height between SG1 and SG2 was not considered here, due to the lack of data on the contents of these exchangeable cations in the soil of experimental plots. Given the above, the differences in mean height between SG1 and SG2 were associated with different $\mathrm{Ca} / \mathrm{Mn}$ ratios in the soil on which these seedlings were growing. Based on the previous assumption, the one-way ANOVA was used to prove that the $\mathrm{Ca} / \mathrm{Mn}$ ratio affects the height growth of Scots pine seedlings. As a result, this analysis revealed that the differences between SG1 and SG2 in the mean height of seedlings were statistically significant $(\mathrm{p}<0.05)$. Although this experiment demonstrated that Scots pine seedlings' height growth rate was higher at a relatively high $\mathrm{Ca} / \mathrm{Mn}$ ratio (195.12/1) in soil than at a relatively low $\mathrm{Ca} / \mathrm{Mn}$ ratio $(45.28 / 1)$ in soil, the optimum value of the $\mathrm{Ca} / \mathrm{Mn}$ ratio in the soil for growth and development of Scots pine, however, is still unknown and needs to be determined in further studies.

\section{Conclusion}

Based on the results of this experiment, the ratio of the exchangeable calcium content to the content of manganese mobile compounds in soil was associated with Scots pine seedlings' height growth rate. In particular, the one-way ANOVA revealed a statistically significant difference $(\mathrm{p}<$ 0.05 ) in mean height between 8-month-old Scots pine seedlings that grew under relatively low (45.28/1) and relatively high (195.12/1) ratios of molal concentrations of exchangeable calcium to manganese mobile compounds in soil. Furthermore, the mean height of Scots pine seedlings that grew at a relatively low $\mathrm{Ca} / \mathrm{Mn}$ ratio in soil was approximately 1.6 times lower than seedlings that grew at a relatively high $\mathrm{Ca} / \mathrm{Mn}$ ratio in the soil. However, the optimum value of the $\mathrm{Ca} / \mathrm{Mn}$ ratio in the soil for Scots pine remains unknown. In addition, the role of some soil properties, such as contents of exchangeable magnesium and mobile aluminum, in the emergence of these differences in mean height of seedlings has not been determined. Thus, both the optimum value of the $\mathrm{Ca} / \mathrm{Mn}$ ratio in the soil for growth and development of Scots pine and the potential synergism and antagonism of the effect of the $\mathrm{Ca} / \mathrm{Mn}$ ratio and content of other base and non-base cations on the growth and development of Scots pine needs to be investigated in further studies.

\section{References}

[1] Sidor, C. G., Camarero, J. J., Popa, I., Badea, O., Apostol, E. N., \& Vlad, R. (2019). Forest vulnerability to extreme climatic events in Romanian Scots pine forests. Science of The Total Environment. doi: 10.1016/j.scitotenv.2019.05.021.

[2] Raatevaara, A., Korpunen, H., Tiitta, M., Tomppo, L., Kulju, S., Antikainen, J., \& Uusitalo, J. (2020). Electrical impedance and image analysis methods in detecting and measuring Scots pine heartwood from a $\log$ end during tree harvesting. Computers and Electronics in Agriculture, 177, 105690. doi: 10.1016/j.compag.2020.105690.

[3] Krakau, U.-K., Liesebach, M., Aronen, T., Lelu-Walter, M.-A., \& Schneck, V. (2013). Scots Pine (Pinus sylvestris L.). Managing Forest Ecosystems, 267-323. doi: 10.1007/978-94007-6146-9 6. 
[4] Jaime, L., Batllori, E., Margalef-Marrase, J., Pérez Navarro, M. Á., \& Lloret, F. (2019). Scots pine (Pinus sylvestris L.) mortality is explained by the climatic suitability of both host tree and bark beetle populations. Forest Ecology and Management, 448, 119-129. doi: 10.1016/j.foreco.2019.05.070.

[5] Meshkova, V. (2020). The Lessons of Scots Pine Forest Decline in Ukraine. Environmental Sciences Proceedings, 3 (1), 28. doi: 10.3390/iecf2020-07990.

[6] Carter, T. S., Clark, C. M., Fenn, M. E., Jovan, S., Perakis, S. S., Riddell, J.,... Hastings, M. G. (2017). Mechanisms of nitrogen deposition effects on temperate forest lichens and trees. Ecosphere, 8 (3), e01717. doi: 10.1002/ecs2.1717.

[7] Liu, T.-W., Wu, F.-H., Wang, W.-H., Chen, J., Li, Z.-J., Dong, X.-J.,... Rennenberg, H. (2011). Effects of calcium on seed germination, seedling growth and photosynthesis of six forest tree species under simulated acid rain. Tree Physiology, 31 (4), 402-413. doi: 10.1093/treephys/tpr019.

[8] Hevia, A., Sánchez-Salguero, R., Camarero, J. J., Querejeta, J. I., Sangüesa-Barreda, G., \& Gazol, A. (2019). Long-term nutrient imbalances linked to drought-triggered forest dieback. Science of The Total Environment. doi: 10.1016/j.scitotenv.2019.06.515.

[9] Yin, D. C., Qi, J. Y., Deng, J. F., Du, H., Deng, X. (2017). Effects of Ectomycorrhizal cooperating with exogenous calcium on Pinus sylvestris var. mongolica growth. China Environmental Science, 37 (6), 2295-2304.

[10] Yin, D., Wang, H., \& Qi, J. (2020). The Enhancement Effect of Calcium Ions on Ectomycorrhizal Fungi-Mediated Drought Resistance in Pinus sylvestris var. mongolica. Journal of Plant Growth Regulation. doi: 10.1007/s00344-020-10197-y.

[11] Schaberg, P. G., DeHayes, D. H., \& Hawley, G. J. (2001). Anthropogenic Calcium Depletion: A Unique Threat to Forest Ecosystem Health? Ecosystem Health, 7 (4), 214-228. doi: 10.1046/j.1526-0992.2001.01046.x.

[12] Grigal, D. F., \& Ohmann, P. R. (2005). CALCIUM AND FOREST SYSTEMS: DIFFUSION FROM DEEP SOURCES. Soil Science, 170 (2), 129-136. doi: 10.1097/00010694200502000-00006

[13] Prietzel, J., Falk, W., Reger, B., Uhl, E., Pretzsch, H., \& Zimmermann, L. (2020). Half a century of Scots pine forest ecosystem monitoring reveals long-term effects of atmospheric deposition and climate change. Global Change Biology, 26 (10), 5796-5815. doi: 10.1111/gcb.15265.

[14] Lim, H., Olsson, B. A., Lundmark, T., Dahl, J., \& Nordin, A. (2020). Effects of whole-tree harvesting at thinning and subsequent compensatory nutrient additions on carbon sequestration and soil acidification in a boreal forest. GCB Bioenergy. doi: 10.1111/gcbb.12737.

[15] Meng, C., Tian, D., Zeng, H., Li, Z., Yi, C., \& Niu, S. (2019). Soil acidification impacts on belowground processes: a metaanalysis. Environmental Research Letters. doi: 10.1088/17489326/ab239c

[16] Fernando, D. R., \& Lynch, J. P. (2015). Manganese phytotoxicity: new light on an old problem. Annals of Botany, 116 (3), 313-319. doi: 10.1093/aob/mcv111.

[17] Singh, S., Tripathi, D. K., Singh, S., Sharma, S., Dubey, N. K., Chauhan, D. K., \& Vaculík, M. (2017). Toxicity of aluminium on various levels of plant cells and organism: A review.
Environmental and Experimental Botany, 137, 177-193. doi: 10.1016/j.envexpbot.2017.01.005.

[18] Rengel, Z. (2011). Soil pH, Soil Health and Climate Change. Soil Health and Climate Change, 69-85. doi: 10.1007/978-3642-20256-8 4.

[19] Van Schöll, L., Keltjens, W. G., Hoffland, E., \& Breemen, N. van. (2005). Effect of ectomycorrhizal colonization on the uptake of $\mathrm{Ca}, \mathrm{Mg}$ and $\mathrm{Al}$ by Pinus sylvestris under aluminium toxicity. Forest Ecology and Management, 215 (1-3), 352360. doi: 10.1016/j.foreco.2005.05.025.

[20] Kula, E., Hrdlička, P., Hedbávný, J., \& Švec, P. (2012). Various content of manganese in selected forest tree species and plants in the undergrowth. Beskydy, 5 (1), 19-26. doi: $10.11118 /$ beskyd201205010019.

[21] Yakist gruntu. Vyznachennia pH (ISO 10390: 2005, IDT) [Soil quality. Determination of $\mathrm{pH}$ (ISO 10390: 2005, IDT)]. (2012). DSTU ISO 10390: 2007 from the 1st January 2009. Kyiv: Derzhspozhyvstandart Ukrainy [in Ukrainian].

[22] Yakist gruntu. Vyznachennia hidrolitychnoi kyslotnosti [Soils quality. Hydrolytic acidity determination]. (2015). DSTU 7537: 2014 from 1st April 2015. Kyiv: Minekonomrozvytku Ukrainy [in Ukrainian].

[23] Pochvy. Opredelenie summy pogloshchennyh osnovanij po metodu Kappena [Soils. Determination of base absorption sum by Kappen method]. (1988). GOST 27821-88 from 1st January 1990. Moscow: Izdatelstvo standartov [in Russian].

[24] Yakist hruntu. Metody vyznachannia orhanichnoi rechovyny [Soils quality. Methods for determination of organic matter]. (2005). DSTU 4289: 2004 from 1st July 2005. Kyiv: Derzhspozhyvstandart Ukrainy [in Ukrainian].

[25] Yakist gruntu. Vyznachennia lehkohidroliznoho azotu metodom Kornfilda [Soils quality. Determination of available hydrolyzable nitrogen by Kornfild method]. (2016). DSTU 7863: 2015 from 1st July 2016. Kyiv: UkrNDNTs [in Ukrainian].

[26] Yakist gruntu. Vyznachennia rukhomykh spoluk fosforu i kaliiu za metodom Kirsanova v modyfikatsii NNTs IHA [Soils quality. Determination of mobile compounds of phosphorus and potassium by Kirsanov method modified by NSC ISSAR]. (2006). DSTU 4405: 2005 from 1st July 2006. Kyiv: Derzhspozhyvstandart Ukrainy [in Ukrainian].

[27] Pochvy. Opredelenie obmennogo kalciya i obmennogo (podvizhnogo) magniya metodami CINAO [Soils. Determination of exchangeable calcium and exchangeable (mobile) magnesium by CINAO methods]. (1985). GOST 26487-85 from 1st July 1985. Moscow: Izdatelstvo standartov [in Russian].

[28] Yakist gruntu. Vyznachennia rukhomoi sirky v modyfikatsii NNTs IHA imeni O. N. Sokolovskoho [Soil quality. Determination of mobile sulfur in modification of NSC ISSAR named after O. N. Sokolovsky]. (2017). DSTU 8347: 2015 from 1st July 2017. Kyiv: UkrNDNTs [in Ukrainian].

[29] Yakist gruntu. Vyznachennia vmistu rukhomykh spoluk midi v grunti $\mathrm{v}$ bufernii amoniino-atsetatnii vytiazhtsi $\mathrm{z}$ pH 4,8 metodom atomno-absorbtsiinoi spektrofotometrii [Soil quality. Determination of copper mobile compounds content in soil in buffered ammonium-acetate extract with $\mathrm{pH} 4,8$ by atomicabsorption spectrophotometry]. (2009). DSTU 4770.6: 2007 from 28th April 2007. Kyiv: Derzhspozhyvstandart Ukrainy [in Ukrainian]. 
[30] Yakist gruntu. Vyznachennia vmistu rukhomykh spoluk tsynku $\mathrm{v}$ grunti $\mathrm{v}$ bufernii amoniino-atsetatnii vytiazhtsi $\mathrm{z}$ pH 4,8 metodom atomno-absorbtsiinoi spektrofotometrii [Soil quality. Determination of zinc mobile compounds content in soil in buffered ammonium-acetate extract with $\mathrm{pH} 4,8$ by atomicabsorption spectrophotometry]. (2009). DSTU 4770.2: 2007 from 28th April 2007. Kyiv: Derzhspozhyvstandart Ukrainy [in Ukrainian].

[31] Yakist gruntu. Vyznachennia vmistu rukhomykh spoluk kobaltu $\mathrm{v}$ grunti $\mathrm{v}$ bufernii amoniino-atsetatnii vytiazhtsi $\mathrm{z} \mathrm{pH}$ 4,8 metodom atomno-absorbtsiinoi spektrofotometrii [Soil quality. Determination of cobalt mobile compounds content in soil in buffered ammonium-acetate extract with $\mathrm{pH} 4,8$ by atomic-absorption spectrophotometry]. (2009) DSTU 4770.5: 2007 from 28th April 2007. Kyiv: Derzhspozhyvstandart Ukrainy [in Ukrainian].

[32] Yakist gruntu. Vyznachennia vmistu rukhomykh spoluk kadmiiu v grunti v bufernii amoniino-atsetatnii vytiazhtsi $\mathrm{z}$ pH 4,8 metodom atomno-absorbtsiinoi spektrofotometrii [Soil quality. Determination of cadmium mobile compounds content in soil in buffered ammonium-acetate extract with $\mathrm{pH} 4,8$ by atomic-absorption spectrophotometry]. (2009). DSTU 4770.3: 2007 from 28th April 2007. Kyiv: Derzhspozhyvstandart Ukrainy [in Ukrainian].

[33] Yakist gruntu. Vyznachennia vmistu rukhomykh spoluk svyntsiu $\mathrm{v}$ grunti $\mathrm{v}$ bufernii amoniino-atsetatnii vytiazhtsi $\mathrm{z}$ pH 4,8 metodom atomno-absorbtsiinoi spektrofotometrii [Soil quality. Determination of lead mobile compounds content in soil in buffered ammonium-acetate extract with $\mathrm{pH} 4,8$ by atomic-absorption spectrophotometry]. (2009). DSTU 4770.9: 2007 from 28th April 2007. Kyiv: Derzhspozhyvstandart Ukrainy [in Ukrainian].
[34] Yakist gruntu. Vyznachennia vmistu rukhomykh spoluk marhantsiu $\mathrm{v}$ grunti $\mathrm{v}$ bufernii amoniino-atsetatnii vytiazhtsi $\mathrm{z}$ pH 4,8 metodom atomno-absorbtsiinoi spektrofotometrii [Soil quality. Determination of manganese mobile compounds content in soil in buffered ammonium-acetate extract with $\mathrm{pH}$ 4,8 by atomic-absorption spectrophotometry]. (2009). DSTU 4770.1: 2007 from 28th April 2007. Kyiv: Derzhspozhyvstandart Ukrainy [in Ukrainian].

[35] Yakist gruntu. Vidbyrannia prob. Chastyna 2. Nastanovy z metodiv vidbyrannia prob (ISO 10381-2: 2002, IDT) [Soils quality. Sampling. Part 2. Guidance on sampling techniques (ISO 10381-2: 2002, IDT)]. (2006). DSTU ISO 10381-2: 2004 from 1st April 2006. Kyiv: Derzhspozhyvstandart Ukrainy [In Ukrainian].

[36] Nakaz pro zatverdzhennia Hihiienichnykh rehlamentiv dopustymoho vmistu khimichnykh rechovyn u grunti, 2020 (Ministerstvo okhorony zdorovia Ukrainy) [Order on approval of the Hygienic regulations of the permissible content of chemicals in the soil, 2020 (Ministry of Healthcare of Ukraine)]. Ofitsiinyi visnyk Ukrainy. [Official Bulletin of Ukraine], 64, 2084. [in Ukrainian].

[37] Naeem, M., Ansari, A. A., \& Gill, S. S. (Eds.). (2020). Contaminants in Agriculture. doi: 10.1007/978-3-030-41552-5.

[38] Yang, N., Zhou, F., \& Wang, J. (2016). Eco-toxicological effects of two kinds of lead compounds on forest tree seed in alkaline soil. Environmental Monitoring and Assessment, 188 (3). doi: 10.1007/s10661-016-5198-2.

[39] Dubenok, N. N., Mazhaiskii, Y. A., Evtyuhin, V. F., \& Tobratov, S. A. (2011). Regularities of heavy metal distribution in soils of forest ecosystems (Exemplified by the Central Part of the Ryazan region). Russian Agricultural Sciences, 37 (3), 224-228. doi: 10.3103/s1068367411030049. 